RISUS - Journal on Innovation and Sustainability ISSN 2179-3565

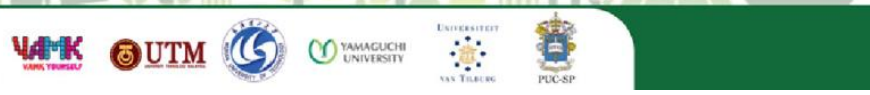

RISUS - Journal on Innovation and Sustainability volume 11, número 3 - 2020

ISSN: $2179-3565$

Editor Científico: Arnoldo José de Hoyos Guevara Editor Assistente: Rosa Rizzi

Avaliação: Melhores práticas editoriais da ANPAD

\title{
RESEARCH ON THE GOVERNANCE OF GOVERNMENT NETWORK PUBLIC OPINION IN THE AGE OF BIG DATA
}

\author{
Pesquisa sobre a governança da opinião pública de redes governamentais na era do Big Data \\ Wang Chunjuan, Zhu Xiao \\ School of Management, Wuhan University of Technology, Wuhan, P.R.China, 430070 \\ E-mail: chunjuanwang882@hotmail.com,541278340@qq.com
}

\begin{abstract}
With the popularization of mobile terminals, information is becoming more and more unimpeded, along with the advent of the era of big data. It brings both opportunities and challenges to the governance of government network public opinion. Using the literature research methodology and the case analysis, combing the research results of domestic and foreign scholars, this paper analyzes the current situation of the network public opinion governance, concludes that having initially built a big data platform for network public opinion and realized the transformation from managing to governing network public opinion, the government strengthens the awareness of the rule of law of network public opinion gradually. Also, it is believed that the government has not fully grasped the opportunity brought about by the big data, with idea, technology as well as ethical dilemma remaining. Finally, from the three aspects it provides development strategies for the government to create a healthy and green network public opinion ecology.
\end{abstract}

Keywords: Big data era, Network public opinion, Government governance, Public opinion management. 


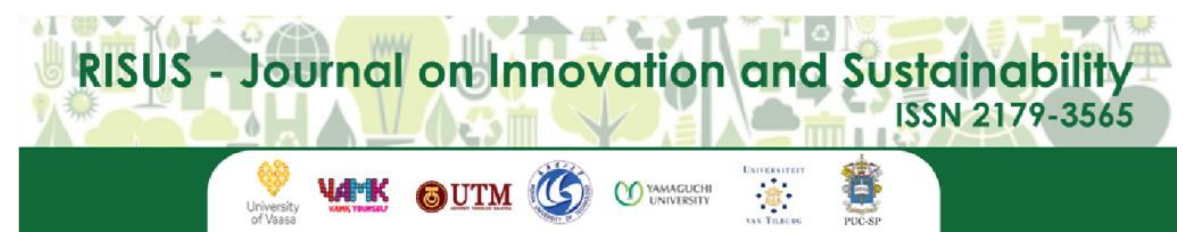

RISUS - Journal on Innovation and Sustainability volume 11, número 3 - 2020

ISSN: $2179-3565$

Editor Científico: Arnoldo José de Hoyos Guevara Editor Assistente: Rosa Rizzi Avaliação: Melhores práticas editoriais da ANPAD

\section{PESQUISA SOBRE A GOVERNANÇA DA OPINIÃO PÚBLICA DE REDES GOVERNAMENTAIS NA ERA DO BIG DATA \\ Research on the governance of government network public opinion in the age of Big Data}

Wang Chunjuan, Zhu Xiao

School of Management, Wuhan University of Technology, Wuhan, P.R.China, 430070

E-mail: chunjuanwang882@ hotmail.com, 541278340@qq.com

\section{RESUMO}

Com a popularização dos terminais móveis, as informações estão se tornando cada vez mais desimpedidas, junto com o advento da era do big data. Ele traz oportunidades e desafios para a governança da opinião pública da rede governamental. Usando a metodologia de pesquisa bibliográfica e a análise de caso, combinando os resultados da pesquisa de acadêmicos nacionais e estrangeiros, este artigo analisa a situação atual da governança de opinião pública em rede, conclui que tendo inicialmente construído uma plataforma de big data para opinião pública em rede e percebido a transformação desde a gestão até a governança da opinião pública da rede, o governo fortalece gradualmente a consciência do estado de direito da opinião pública da rede. Além disso, acredita-se que o governo não aproveitou totalmente a oportunidade trazida pelo big data, permanecendo a ideia, a tecnologia e o dilema ético. Finalmente, a partir dos três aspectos, fornece estratégias de desenvolvimento para o governo criar uma ecologia de opinião pública em rede saudável e verde.

Palavras-chave: Era do Big Data, Opinião pública em rede, Governança governamental, Gestão da opinião pública. 


\section{INTRODUCTION}

Compared with previous Internet, Internet of things and cloud computing, today's big data, as another emerging technology of the era, imposes a significant impact on the development of human society, daily life and work. According to the 43rd report on the status of Internet development in China, released by the China Internet Network Information Center (CNNIC), as of December 2018, the size of Internet users reached 829 million, with new Internet users as 56.53 million over the whole year, and the penetration rate as $59.6 \%$, thus forming the world's largest public opinion filed.(as shown in the following picture). China's complicated network public opinion environment has been followed by a series of public opinion disturbances, which has imposed various adverse effects on the daily life of the public and the political stability of the country. Therefore, how to construct the optimal path of network public opinion governance in the era of big data is very important.

Figure 1 The Number of Internet Users and Internet Popularization Rate

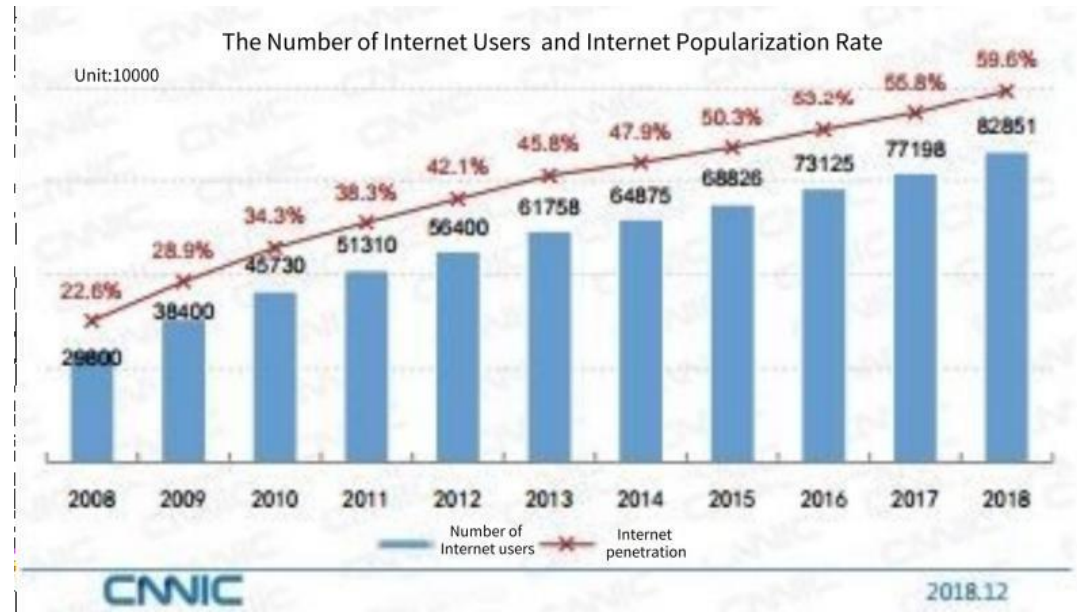

Western public opinion is relatively open and stable, and the negative effect of public opinion is relatively low, thereby making the government adopt more liberal means. As far as network public opinion is concerned, Porten-CheéP and Eilders C. (Porten-CheéP and Eilders C.,2015) believed that network public opinion has the nature of "silent spiral". McQuailD (McQuail D,1997) believed that the communication revolution triggered by the Internet is essentially manifested in the transformation of audiences from passive information receivers as well as consumers to active information searchers, distributors as well as exchangers. In terms of the governance of network public opinion, James Allan(Allan,2003) found that Topic Detection and Tracking (TDT) technology has been applied in network public opinion data analysis as early as the 1990s. Kumaran(Kumaran,2004) suggested to promote the use of natural language processing techniques to aid statistical strategies for new event monitoring. Goncalves P And Benevenuto F (Goncalves P And Benevenuto F,2013) believed that we can use the Positive and Negative Affect Schedule-t (Positive And Negative Affect Schedule-t) to measure emotions in online media, to calculate standardized scores of various emotions, thus analyzing users' responses to specific events.

Chinese scholars and foreign scholars show a great difference in the research direction and emphasis. At present, network public opinion researches from the perspective of the government have been favored and pursued by abundant scholars who have put forward plenty of views worth discussing, which are reflected mainly in the following three aspects: network public opinion monitoring, guidance and response at big data age.

Big Data and network public opinion monitoring refers to the automatic detection of big data, functional separation, statistical analysis and so on. Ren Dejing (Ren Dejing,2016) proposed that the government should 
conduct correlation analysis of massive as well as disorderly network public opinion data before specific network public opinion crisis occurs by combining with big data in-depth analysis technology, to explore its value, and to contribute to early warning of public opinion crisis. Believing that the government's detection of network public opinion remains at the level of public security, Zhang Shuoyang (Zhang Shuoyang,2016) contended that it should collect, process and analyze information and manage public opinion through such devices as e-government private network and terminal storage based on cloud platform storage and calculation.

Big data and network public opinion guidance, that is, the government uses various network carriers to communicate with netizens, so as to develop in a healthy direction through guiding network public opinion. Xu Jinghong and Jiang Qiulan (Xu Jinghong and Jiang Qiulan,2012), from the perspective of communication, analyzed the problems existing in the microblog of party and government institutions under the guidance of network public opinion, along with the proposal of suggestions for improvement: optimizing interaction, treating each other honestly, changing from indoctrination to participation; Zhang Dong and Liu Jianhui (Zhang Dong and Liu Jianhui,2008) analyzed the basic principles of agenda setting by taking the Hangzhou nanny arson case as an example to propose strategies such as strengthening the sense of responsibility, improving interactive mechanism and improving media literacy.

Big data and network public opinion response indicates that the government takes a series of measures to solve network public opinion crisis and establish a good image of government departments. Gao Hang(Gao Hang,2016), from the perspective of the system dynamics method, proposed that we can reduce the investigation on external factors such as supervision institutions and personnel quality, and increase the research on internal factors such as the degree of attention, hardware and software supporting conditions, which are closely correlated with government public opinion. Li Xueyan (Li Xueyan,2018) proposed to build a timely response system in the outbreak period of network public opinion, along with the promotion of the response as well as disposal in the diffusion period of network public opinion.

The research views of domestic and foreign scholars mentioned above are of considerable reference value, but there is still room for further improvement. First of all, the existing researches demonstrate that "big data" and "network public opinion governance" are not very closely linked. Even more, abundant researches are trapped in a circle of "old wine in new bottle", failing to apply big data fully, thereby making it difficult to seize the opportunity provided by big data to construct an effective and realistic path. Secondly, a large part of research is carried out based on certain socially hot events, followed by the analysis of the network public opinion. In other words, it still focuses on a certain "network public opinion crisis", without paying attention to "network public opinion governance", thus failing to dig out the characteristics of the current government's governance of network public opinion, and neglecting the governance effect achieved by the government.

\section{THE CURRENT SITUATION OF GOVERNMENT GOVERNANCE UNDER CHINA'S NETWORK PUBLIC OPINION}

\subsection{Initially build a big data platform for network public opinion}

China's e-government construction has laid a solid foundation for the establishment of China's big data platform for network public opinion. For example, the notion of "two nets, one station, four databases and twelve operation systems" was established in 2003. Subsequently, the e-government system developed rapidly. By December 2018, China have 394 million users of online government services, accounting for 47.5 percent of the total Internet population, along with 2,817,962 government websites. Moreover, it's not difficult to find that "Internet + e-government service" in our country has been further deepened, due to information technologies such as the Internet, big data and AI, have been applied by governments at all levels to further improve the efficiency of government services. Even more, it serves as the main source of information collection and the premise of data analysis. 


\subsection{Initially realize the transformation from managing to governing network public opinion}

The main task of management is to design and maintain an environment which is capable of achieving the maximum objectives with existing resources. The original intention of governance is to serve, which is fundamentally different from that of the traditional government management. With the development of big data and the change of network public opinion, government departments at all levels have begun to actively seek more effective ways to govern network public opinion, and to strengthen the interaction between officials and people by establishing government affairs micro-blogs and releasing various government affairs information in real time. At the same time, the government has also strengthened the cooperation with the network media, requiring the microblog real-name authentication, and attaching importance to the improvement of the quality of Internet users. This is conducive to smooth public opinion expression channels, and can contribute to improving the credibility of the government and reducing online rumors.

\subsection{Gradually strengthen the awareness of the rule of law of network public opinion}

At present, China attaches great importance to protecting the legitimate rights as well as the interests of citizens, legal persons and other organizations. Regulations on the Administration of Microblog Information Services was issued in February 2018, which aims to clarify the main responsibilities of microblog service providers, and achieve the authentication of real identity information as well as administrative management. Followingly, Has the Attribute of Public Opinion and Social Mobilization Ability of Internet Information Services Security Assessment Rules released in November aims to urge and guide information service providers with public opinion attribute or social mobilization ability to fulfill the security management obligations stipulated by law and guard against the harm caused by the spread of illegal information such as rumors and false information. In short, these laws and regulations have established a basic institutional framework, thus providing legal basis and legal protection for citizens in terms of safeguarding their legitimate rights and interests.

\section{GOVERNMENT GOVERNANCE DILEMMA UNDER CHINA'S NETWORK PUBLIC OPINION}

\subsection{Ideological Dilemma}

Ideas guide people to understand and transform the world through guiding their ability and activities. Mistakes and deviations will occur in in the government's network public opinion management if the concept cognition of "big data" fails to keep up. China embraces a large number of Internet users, with the source of big data at the forefront. However, at present, China lacks the awareness of integrating, analyzing and utilizing big data, thus resulting in the final total data falling behind developed countries. For example, the heavy rain event in Xingtai of Hebei province on July 19, 2016, was very urgent, which, however, didn't attract the attention of the government until the spread of netizens and we-media on the 22nd. The state media, on the other hand, at the end of the chain, has been slow to respond natural and man-made disasters which constantly test the government's prediction ability. Thus, analyzing and mining big data over the years is of great positive significance to prevent malignant public opinion events.

\subsection{Technical Difficulties}

"Science and technology are the first productive force", which also serves as an important guarantee and technical premise for the government to improve the ability of network public opinion governance in the era of big data. Big data is of rich connotation. To be more specific, only at the technical level, the fields intersecting with big data involve mining and analysis of association rules, pattern recognition, integrated learning, prediction model, regression statistics, time series analysis, cluster analysis and so on. After the big data era, the Chinese government's information processing level has achieved preliminary results, but there is still a lot of room for growth in terms of technology application. More specifically, local governments at all levels, especially the local governments at the grass-roots level, lack strong consciousness of network public opinion forecasting technology,

RISUS - Journal on Innovation and Sustainability, São Paulo, v. 11, n.3, p. 04-12, mai./jun. 2020 - ISSN 2179-3565 
with a shortage of professional talents as well as technical processing system, which leads to screening of vast amounts of data network public opinion and timely judgement and warning, thus restricting the combing, guiding and handling of subsequent network public opinion.

\subsection{Ethical Dilemma}

At present, government departments, increasingly more superstitious, rely on science and technology to detect and manage network public opinions. Specifically, they pay one-sided attention to the intervention of public opinions, but ignore netizens, the main body of network public opinions. Even more, they lack the awareness of solving social problems reflected in network public opinion which, in essence, serves as a part of public opinion. Therefore, the most fundamental purpose of the government which carries out network public opinion governance should be to establish effective communication with the public and society by taking the network as a medium, so as to contribute to understanding public opinion, and releasing information more effectively. Otherwise, a new round of problems may be triggered if the fundamental problems and the underlying causes can't be identified, which is not conducive to strengthening the two-way and symmetrical communication between the government and the public, and to alleviating as well as eliminating the crisis of network public opinion.

\section{OPTIMIZATION AND IMPROVEMENT OF CHINA'S GOVERNMENT NETWORK PUBLIC OPINION GOVERNANCE}

\subsection{Establish and spread the concept of "big data" for network public opinion governance}

Traditional network public opinion governance concept means to conduct qualitative analysis, find the source, and finally take countermeasures after the occurrence of public opinion events. Obviously, this idea is not applicable to the big data era. Only by setting up the concept of "big data", starting from monitoring and prediction, carrying out quantitative analysis and finding out all relevant factors, can we prevent problems from happening and truly realize the open sharing of data. See figure 2 for details.

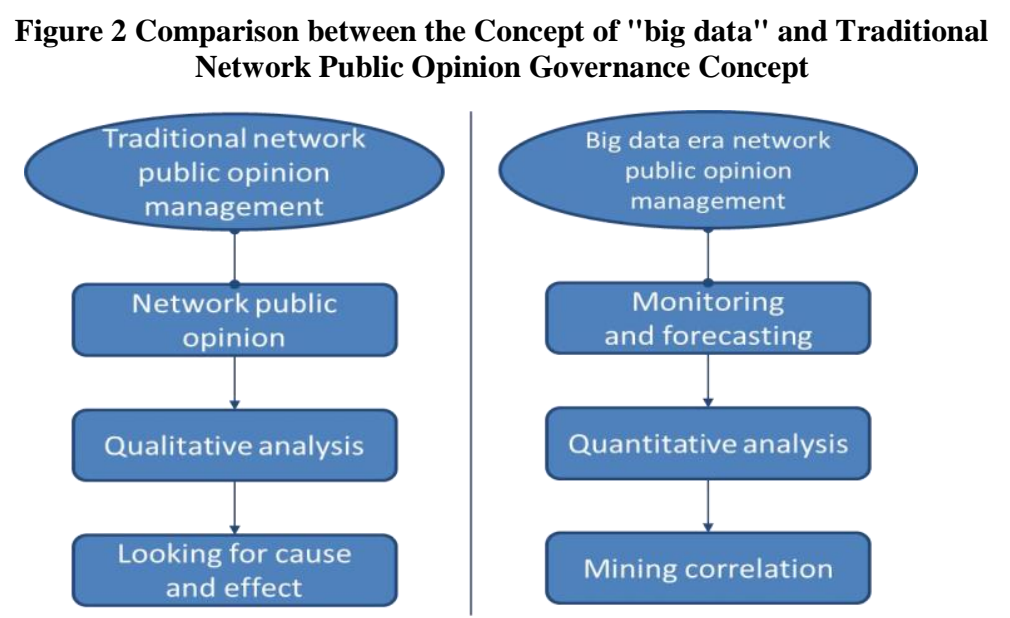

First of all, whether the concept of "big data" can really be implemented depends on the government and its managers in the final analysis. Therefore, it is necessary to implement the policy intentionally, to organize the learning and sharing of "big data" concept, and to render the atmosphere of "big data" concept.

Secondly, it is not feasible that data collection of network public opinion governance relies solely on the government to sing a "one-man show", which requires the participation of multiple social subjects. 


\subsection{Develop and strengthen "big data" technology for network public opinion governance}

On the one hand, we should step up the application awareness of big data. Due to in the face of massive network public opinion information, Internet computer technology and big data analysis technology play an indispensable role in information identification and screening, it is essential for us to focus more on promoting research and development of disciplines and key technologies related to big data, such as artificial intelligence, mass data storage and management, real-time big data processing etc.

On the other hand, efforts should be made to cultivate professionals in relevant fields. At present, some Internet companies have been cooperating with universities to carry out related activities.

However, the talent training mechanism for the subdivision of government network public opinion governance under big data has not yet emerged, thus making it a feasible way to build a long-term training mechanism of big data talents by introducing overseas talents in the field of big data and expanding the major of big data through universities.

\subsection{Establish mechanisms to promote "public interaction" for network public opinion governance}

"Emotional resonance" with netizens refers to giving the public an outlet to channel their emotions. Through this way, governments at all levels can set up interactive communication platforms for officials and citizens by setting up government micro-blogs, portal websites and official accounts, so as to promote electronic government office, to open and transparent government affairs, and to step up the communication between the government and the public.

Facts have proved effectiveness of establishing information release mechanism, releasing information timely, initiatively, openly and transparently, letting Internet users know what they want to know, wining the favor of public opinion, timely eliminating the negative impact exerted by incorrect information in society, and achieving "emotional resonance" with Internet users.

\section{CONCLUSION}

Research review: Based on existing literature on Internet public opinion governance in the era of big data, this paper further analyzes the current situation of Internet public opinion governance, as well as the achievements and shortcomings of the government in the governance of Internet public opinion. Followingly, combined with the historical background of big data, the paper puts forward suggestions on establishing and disseminating the concept of "big data", developing and strengthening the technology of "big data", and establishing and promoting the mechanism of "public interaction".

Research deficiencies and prospects: due to the author's lack of relevant practical experience, the suggestions on the governance path of network public opinion are inevitably inadequate and idealistic. At the same time, the author's analysis and demonstration on the governance of government network public opinion combined with big data is not profound enough. Thus, the author will understand and analyze this topic in the future practical researches deeply, and try to make his argument more scientific and powerful, so as to contribute to the government to creating a healthy network public opinion ecology.

\section{Acknowledgement}

This paper is supported by National innovation and entrepreneurship training program for college students + S201910497095 


\section{REFRENCES}

GAO, Hang. System dynamics modeling and simulation research on government public opinion response ability [J]. Intelligence science, 2016,34 (02):133-138 (In Chinese)

GE, Wei. Research on the dilemma and countermeasures of network public opinion governance [J]. Journal of public security (journal of Zhejiang police college), 2016(04):35-40 (In Chinese)

G. KUMARA and J.ALLAN. Text Classification and Named Entities for new Event Detection [A]. Proceedings of the SIGIR Conference on Research and Development in Information Retrieval [C].

Sheffield, South Yorkshire: ACM, 2004:297-304

GONCALVES P, BENEVENUTO F, CHA M.PANAS-t: A Pychometric Scale for Measuring Sentiments on Twitter[J]. Systems, Man, and Cybernetics, Part C: Applications and Reviews, 2013:1-12

HU, Hongbin. Dual situation and solution of national governance capacity building in the era of big data [J].

Socialist research, 2014(04):89-95 (In Chinese)

JAMES, Allan, AO, Feng, ALVARO, Bolivar. Flexible Intrinsic Evaluation of Hierarchical Clustering for TDT $[\mathrm{J}]$. Proceedings of the Twelfth International Conference on Information and Knowledge Management, 2003:263270

JIN, Yi, XU, Hongyan. System construction of government network public opinion governance in the era of big data [J]. Journal of party school of Tianjin municipal party committee, 2008, 20 (01):78-83 (In Chinese)

LI, Xueyan. Research on coping strategies of local government network public opinions in the we-media environment [D]. Heilongjiang University, 2018:84-87 (In Chinese)

LI, Zheng. Thoughts and countermeasures of Chinese network public opinion governance from the perspective of big data[J]. News communication, 2019(05):18-20 (In Chinese)

MCQUAIL, D. Audience. Analysis [M].London: Sage Publications, 1997:129

PENG, Zhihui. Research status and reflection of public opinion on government vision network [J]. Intelligence journal, 2014, 33(09):93-99 (In Chinese)

PORTEN-CHEÉP, Eilders C. Spiral of Silence Online: How Online Communication Affects Opinion Climate Perception and Opinion Expression Regarding the Climate Change debate [J].Studies in Communication Sciences, 2015,15(1):143

QING, Lixin. Management of network public opinions in the era of innovative big data[J]. Big data era, 2018(09):68-70 (In Chinese)

REN, Dejing. Social governance in the context of big data era by utilizing network public opinion [J]. Journal of Shenyang cadres, 2016, 18 (03):41-43 (In Chinese)

XU, Jinghong, JIANG, Qiulan. Problems and countermeasures of party and government Weibo in the guidance of network public opinion [J]. Contemporary communication, 2012(04):82-84 (In Chinese) 
XIAO, Haiyan, ZHU, Fengxia. Systematic governance strategy of network public opinion under the national big data strategy [J]. Journal of Tianshui university of administration, 2017,18(02):39-42 (In Chinese)

WANG, Bo. Research on network public opinion and social governance in the age of big data [D]. Yunnan University of finance and economics, 2016:64-100 (In Chinese)

WANG, Linlin, Qi Nannan, Ai Feng. Research on governance model of network public opinion in the era of big data [J]. Journal of China academy of electronic sciences, 2013, 13(05):502-505 (In Chinese)

WANG, Haijian. Capacity building of network public opinion governance in universities in the era of big data[J]. Journal of Xinyang normal university (philosophy and social science edition), 2015, 35(03):85-88 (In Chinese)

ZHANG, Aijun. Research on the change of campus network public opinion management in the era of big data [J]. Business, 2016(04):211+210 (In Chinese)

ZHANG, Dong, LIU, Jianhui. Research on network public opinion guidance in the era of we media -- from the perspective of agenda setting [J]. Journal of Chongqing university of posts and telecommunications (social science edition), 2008, 30(02):80-86 (In Chinese)

ZHANG, Shuoyang. Research on network public opinion and network social governance in the era of big data[J]. Informatization construction, 2016(04):10-11 (In Chinese)

ZENG, Wangfeng. Research on government network public opinion management in the era of big data [D]. Hunan University, 2017:34-38 (In Chinese)

ZHOU, Wei. Network public opinion in the era of we media, government response to difficulties and solutions [J]. Intelligence journal, 2008, 37(04):100-105+99 (In Chinese) 